\title{
Acceleration Breaks the Cells Defense Mechanisms against Vibration in Anthemis gilanica Calli
}

\author{
Halimeh Hassanpour $\mathbb{D}^{1},{ }^{1}$ Vahid Niknam, ${ }^{2}$ and Sadaf Salami ${ }^{2}$ \\ ${ }^{1}$ Aerospace Research Institute, Ministry of Science Research and Technology, Tehran 14665-834, Iran \\ ${ }^{2}$ School of Biology, College of Science and Center of Excellence in Phylogeny of Living Organisms in Iran, \\ University of Tehran, Tehran, Iran \\ Correspondence should be addressed to Halimeh Hassanpour; hassanpour@ari.ac.ir
}

Received 26 September 2020; Revised 9 February 2021; Accepted 11 March 2021; Published 22 March 2021

Academic Editor: Mehdi Rahimi

Copyright $\odot 2021$ Halimeh Hassanpour et al. This is an open access article distributed under the Creative Commons Attribution License, which permits unrestricted use, distribution, and reproduction in any medium, provided the original work is properly cited.

\begin{abstract}
Vibration is a mechanical stress which happens in nature and affects many biological aspects of plants. In this research, the effect of acceleration and vibration was investigated on some physiological and biochemical responses of Anthemis gilanica in vitro. Calli were induced from leaf (LS) and root segments (RS) and were applied to different frequencies of vibrations ( 0,50 , and $100 \mathrm{~Hz}$ ) and accelerations (1,2, and $4 \mathrm{~g}$ ) on the A. gilanica calli for $30 \mathrm{~min}$. Results showed that vibration significantly increased relative water content (RWC), growth parameters, protein and proline contents, ascorbate peroxidase (APX), peroxidase (POX), and superoxide dismutase (SOD) activities and decreased total carbohydrate, malondialdehyde (MDA), $\mathrm{H}_{2} \mathrm{O}_{2}$ contents, and polyphenol oxidase (PPO) activity in both LS and RS calli. Inversely, increase of acceleration in vibrated calli decreased growth parameters, RWC, protein content, and POX activity and induced proline and carbohydrate accumulations, SOD, APX, and PPO activities as compared to vibration alone. Different responses of two callus types were observed, and the highest growth, protein content, and membrane stability were observed in LS calli as compared to RS calli. It found that high acceleration amplitude intensified the resonance effect of vibration by induction of lipid peroxidation and oxidative stress damage in A. gilanica.
\end{abstract}

\section{Introduction}

Plants in nature are motivated by various types of mechanical stimulations such as vibration, electromagnetic field, waves, sounds, and so on [1]. Mechanical forces can sense by cells and transfer to the nucleus through cytoskeleton and affecting many cellular activities [2] and biological characteristics of plants [3]. For example, cell division increased in some pea species for androgenesis induction using electroporation [4]. The direction of new cell wall is changed by mechanical stress [5]. Moreover, shoot length and thickness decreased in Capsella bursa-pastoris under mechanical stress [6].

Vibration is a kind of mechanical stress which can be classified into two categories, sinusoidal and random. Sinusoidal vibration is mostly used in biological studies $[7,8]$.
Amplitude (usually acceleration or displacement) and frequency are two parameters to define sinusoidal vibration. The amplitude can be constant or variable. When acceleration is used to define amplitude, its unit is usually $g$ or meter per second squared $\left(\mathrm{m} / \mathrm{s}^{2}\right)$. One $g$ is equal to the acceleration produced by the earth's gravity and is equivalent to $9.8 \mathrm{~m} / \mathrm{s}^{2}$ [9]. Recently, more consideration has been done to the impact of vibration at different frequencies and acceleration on biology. The physical and biochemical mechanisms by which cells can perceive and respond to vibrations are largely unknown. Vibration at different frequencies and accelerations can affect cellular fluid viscosity and induce matrix deformation, oscillatory motion against the gravitational force, and fluid shear stress [10]. The fluidity of cell membrane changes under vibration, and different physiological and biochemical responses have 
happened in plant cells. For example, vibration at various frequencies induced growth and fiber accumulation in Gerbera jamesonii acrocarpous callus [11], secondary metabolite, and soluble protein content in Camptotheca acuminata [12], cell proliferation [13], and antioxidative enzyme activity in Triticum aestivum seedling [14]. Increased accumulation of reactive oxygen species (ROS) content is observed in wheat seedling [14] and Arabidopsis [15]. Also, the contents of sugar, ATP, and hormones are changed significantly under vibration $[16,17]$.

Anthemis gilanica Bornm. \& Gauba is a medical plant belonging to Asteraceae family and is an endemic plant of Iran [18]. The cytotoxic activity of various Anthemis species against cancer cell lines is ascribed to the presence of different natural products such as sesquiterpenes lactones, and flavonoids with antimicrobial and antifungal activities [19-21]. So, access to specific conditions of A. gilanica cell culture with more growth and study of its antioxidant capacity is very valuable. Until now, some studies have been reported about the impact of different vibration frequencies on physiological and biochemical responses of plants $[11,14]$. However, there is little information available about the mixed effect of vibration and acceleration on plant cell (Uchida and Yamamoto, 2002). Acceleration magnitude can induce cellular fluid shear stress [22] and affect various cellular responses under vibration. Antioxidative responses of the mixed impact of vibration and acceleration have never been studied before on any species. So, we studied the mixed effect of vibration and acceleration on cell growth induction and antioxidative responses in A. gilanica callus.

\section{Materials and Methods}

2.1. Callus Culture, Vibration, and Acceleration Treatments. Seeds of A. gilanica were gathered from Rudsar, Gilan province of Iran. The seeds were sterilized in $70 \%(\mathrm{v} / \mathrm{v})$ ethanol for one minute, then $15 \%(\mathrm{v} / \mathrm{v}) \mathrm{NaOCl}$ for $10 \mathrm{~min}$, and finally washed three times with sterile distilled water, and then were cultured on 1/2 MS medium [23] containing $3 \%$ sucrose and $7 \%$ agar-agar at $25 \pm 2{ }^{\circ} \mathrm{C}, \mathrm{pH} 5.7,60 \%$ relative humidity, and a $16 \mathrm{~h}$ artificial light (white fluorescent lamps giving light intensity $46 \mu \mathrm{mol} \mathrm{m} \mathrm{m}^{-2} \mathrm{~s}^{-1}$ ) pursued by the 8 -hour dark period. After 4 weeks of culture, the $0.5-0.6 \mathrm{~cm}$ leaf (LS) and root (RS) segments were placed in a solid MS medium supplemented with 2,4-dichloro-phenoxyacetic acid (2, 4-D, $0.5 \mathrm{mg} \mathrm{L}^{-1}$ ) and kinetin (KIN, $0.5 \mathrm{mg} \mathrm{L}^{-1}$ ) for callus initiation. Calli ( $c a .0 .3-0.4 \mathrm{~g}$ ) were subcultured to the MS solid medium with the same hormonal composition. Then, after one week, different frequencies of sinusoidal vibration $(0,50$, and $100 \mathrm{~Hz})$ with various accelerations $(1,2$, and $4 \mathrm{~g}$ ) along the $Y$ axis were applied on callus tissues for $30 \mathrm{~min}$, as is shown in Figure 1. Acceleration amplitudes and vibration frequency were generated using an electromechanical shaker composed of a power amplifier type SA-36, a signal generator, and a vibration exciter type DC-3200, China. The program was defined with a control Swept Sine Software. Calli are grown in a growth chamber with the same condition for three weeks and then were gathered for biochemical and physiological analyses.
2.2. Growth and Relative Water Content (RWC). For detection of dry weight, the samples were put at $4^{\circ} \mathrm{C}$ for $72 \mathrm{~h}$ on five individual calli per treatment. RWC content was also defined according to [24].

2.3. Lipid Peroxidation and $\mathrm{H}_{2} \mathrm{O}_{2}$ Level. The lipid peroxidation was defined based on malondialdehyde (MDA) content according to [25]. Hydrogen peroxide $\left(\mathrm{H}_{2} \mathrm{O}_{2}\right)$ content was measured by [26], and the absorbance was read at $390 \mathrm{~nm}$.

2.4. Proline and Carbohydrate Content. Proline content of each sample was assayed based on [27], and the absorbance was recorded at $520 \mathrm{~nm}$. Proline content of each sample was calculated from a standard curve. Carbohydrate content was determined based on [28].

2.5. Total Protein. Total protein content was quantified based on the method of [29]. Absorption of the samples was measured at $595 \mathrm{~nm}$ using a standard curve of protein content and expressed as $\mathrm{mg} \mathrm{g}^{-1} \mathrm{FW}$. Bovine serum albumin (BSA) was used as a standard.

\subsection{Antioxidant Enzyme Assay}

2.6.1. Superoxide Dismutase (SOD) Activity. SOD activity was estimated by monitoring its capacity to inhibit nitroblue tetrazolium (NBT) reduction at $560 \mathrm{~nm}$. Isozymes of SOD were defined based on the photochemical staining method as described by [30]. For selective inhibition of various SOD isoforms, the gel was put in $\mathrm{KCN}$ ( $3 \mathrm{mM}$, inhibitor of $\mathrm{Cu} / \mathrm{Zn}$ $\mathrm{SOD}$ ) and then in $5 \mathrm{mM} \mathrm{H}_{2} \mathrm{O}_{2}$ (inhibitor of Fe-SOD and $\mathrm{Cu}$ / $\mathrm{Zn}-\mathrm{SOD})$ for $20 \mathrm{~min}$ [31].

2.6.2. Peroxidase (POX) Activity. Specific POX activity was estimated based on [32]. The absorbance was determined at $530 \mathrm{~nm}$. The POX activity was determined as $1 \mu \mathrm{mol}$ of benzidine oxidized per min per mg protein (unit, $\mathrm{mg}^{-1}$ protein). POX isoenzymes appeared by putting the gels in acetate buffer $(0.2 \mathrm{M}, \mathrm{pH} 4.8)$ including $\mathrm{H}_{2} \mathrm{O}_{2}(3 \%)$ and benzidine $(4 \%)$ in methanol $(50 \%)$ at room temperature until the brown color appeared [33].

2.6.3. Polyphenol Oxidase (PPO) Activity. The activity of polyphenol oxidase was estimated based on [34]. The rise of absorbance was recorded at $430 \mathrm{~nm}$. The PPO activity was detected as absorbance change per minute per mg protein (unit, $\mathrm{mg}^{-1}$ (protein)).

2.6.4. Ascorbate Peroxidase (APX) Activity. The APX activity was determined by monitoring the reduction in absorbance at $290 \mathrm{~nm}$ because of ascorbate oxidation based on [35]. 
2.7. Statistical Analysis. Data from different experiments were analyzed by one-way analysis of variance (ANOVA) using SPSS (version 18) in a randomized complete block design. Data are the mean \pm SE of four or five replications in each group. All data were conducted to analyze, and the significance of the differences among treatment means was examined using a least significant differences (LSD) test at the level of $P<0.05$.

\section{Results}

3.1. Callus Growth and Tissue Water Content. Various frequencies of vibration and acceleration induced different responses in growth parameters of A. gilanica. Fresh and dry weight significantly increased in both LS and RS calli under vibration, and the highest growth was observed in LS than that of RS calli (Table 1). Vibration at $50 \mathrm{~Hz}$ frequency induced a $46.15 \%$ and $51.72 \%$ increase of fresh weight in LS and RS calli compared to the control, respectively. Application of acceleration to vibrated calli reduced growth parameters, and the increase of its dose decreased growth further. At $4 \mathrm{~g}$ acceleration and $50 \mathrm{~Hz}$ vibration, a $31.57 \%$ and $29.54 \%$ decrease of dry weight were observed in LS and RS calli compared to vibration alone, respectively. The LS and RS calli were yellow in color at control and green at $50 \mathrm{~Hz}$ and $100 \mathrm{~Hz}$ frequencies of vibration after three weeks of treatment application. With the increase of the acceleration level, the calli became light yellow and brownish, especially at $4 \mathrm{~g}$ acceleration and $100 \mathrm{~Hz}$ frequency.

RWC significantly went up with vibration intensified $(50 \mathrm{~Hz}$ and $100 \mathrm{~Hz}$ ), and a $19.55 \%$ and $27.23 \%$ induction in RWC was determined at $50 \mathrm{~Hz}$ frequency in LS and RS compared to the control, respectively (Table 1). An increase of the acceleration level decreased RWC in A. gilanica calli under vibration. At $4 \mathrm{~g}$ acceleration under $50 \mathrm{~Hz}$ vibration, LS and RS calli showed a $48.06 \%$ and $32.41 \%$ decrease of RWC compared to vibration alone, respectively.

3.2. Protein Content. Sinusoidal vibration and acceleration significantly changed the total protein content in A. gilanica calli. At $50 \mathrm{~Hz}$ and $100 \mathrm{~Hz}$ frequencies, vibration significantly enhanced protein content compared to control $(P<0.05)$ (Table 1$)$. The frequency of $50 \mathrm{~Hz}$ resulted in an increase of $59.10 \%$ and $69.62 \%$ protein content in LS and RS calli compared to the control, respectively. Increase of the acceleration level from $1 \mathrm{~g}$ to $4 \mathrm{~g}$ reduced significant protein content under vibration compared to the control $(1 \mathrm{~g})$, and minimum protein was determined at $4 \mathrm{~g}$. A $38.57 \%$ and $29.19 \%$ decrease of protein content was observed under $100 \mathrm{~Hz}$ vibration with $4 \mathrm{~g}$ acceleration in LS and RS calli as compared with vibration alone, respectively.

3.3. Proline and Carbohydrate Content. Significant increase in proline accumulation was observed with the rise of vibration frequency, and $100 \mathrm{~Hz}$ frequency showed a $41.30 \%$ and $50.33 \%$ increase in proline content in LS and RS calli compared to the control, respectively $(P<0.05)$ (Figure 2(a)). An increase in the acceleration level induced more proline accumulation than vibration alone in A. gilanica. At $100 \mathrm{~Hz}$ frequency and $4 \mathrm{~g}$ acceleration, LS and RS calli showed a $16.29 \%$ and $25.61 \%$ increase of proline content as compared to vibration alone, respectively.

Total carbohydrate content significantly decreased at $50 \mathrm{~Hz}$ and $100 \mathrm{~Hz}$ frequencies in both A. gilanica calli. Vibration induced a $21.11 \%$ and $13.48 \%$ decrease of total carbohydrate at $100 \mathrm{~Hz}$ in LS and RS calli, respectively. The mixed effect of acceleration and vibration caused a significant enhancement of total carbohydrate compared to the control, and a $30.56 \%$ and $27.88 \%$ increase of total carbohydrate was observed at $50 \mathrm{~Hz}$ with $4 \mathrm{~g}$ acceleration $(P<0.05)$ (Figure 2(b)).

3.4. $\mathrm{H}_{2} \mathrm{O}_{2}$ and Lipid Peroxidation Levels. Vibration significantly decreased $\mathrm{H}_{2} \mathrm{O}_{2}$ content in A. gilanica calli $(P<0.05)$, and $50 \mathrm{~Hz}$ frequency showed the minimum $\mathrm{H}_{2} \mathrm{O}_{2}$ level (Figure 3(a)). At $50 \mathrm{~Hz}$ vibration, a $19.04 \%$ and $23.07 \%$ decrease of the $\mathrm{H}_{2} \mathrm{O}_{2}$ level was observed in LS and RS calli compared to the control, respectively. Conversely, the mixed effect of acceleration and vibration significantly increased the $\mathrm{H}_{2} \mathrm{O}_{2}$ level, especially in RS calli. A $31.64 \%$ and $43.04 \%$ increase of the $\mathrm{H}_{2} \mathrm{O}_{2}$ level was observed at $100 \mathrm{~Hz}$ with $2 \mathrm{~g}$ and $4 \mathrm{~g}$ acceleration in RS calli compared to vibration alone, respectively.

MDA content was related to the $\mathrm{H}_{2} \mathrm{O}_{2}$ level and decreased under vibration compared to control (Figure 3(b)). LS calli indicated a lower MDA level than RS calli, and a $26.22 \%$ and $18.03 \%$ decrease of this parameter was observed at the frequencies of $50 \mathrm{~Hz}$ and $100 \mathrm{~Hz}$ compared to control. The mixed effect of acceleration and vibration significantly increased the MDA level as compared to control. In RS calli, a $36.61 \%$ and $84.15 \%$ increase of the MDA level were observed at $100 \mathrm{~Hz}$ with $2 \mathrm{~g}$ and $4 \mathrm{~g}$ acceleration as compared to vibration alone, respectively.

3.5. Antioxidant Enzymes Activities. The activities of antioxidant enzymes including SOD, POX, APX, and PPO under acceleration and vibration are shown in Figures 5-6, respectively. Vibration significantly induced SOD activity, and the maximum activity was found out at $50 \mathrm{~Hz}$ frequency compared to the control $(P<0.05)$ (Figure $4(\mathrm{a}))$. The mixed effect of vibration and acceleration strongly increased SOD activity, especially at $4 \mathrm{~g}$ acceleration compared to vibration alone. At frequency of $50 \mathrm{~Hz}$, acceleration $(4 \mathrm{~g})$ induced a $42.94 \%$ and $24.43 \%$ increase of SOD activity in LS and RS calli compared to the vibration alone, respectively. Electrophoretic profiles of SOD showed different SOD isoforms (Figure 4(b)). Two SOD isoforms were observed in both LS and RS calli: an Mn-SOD isoform and $\mathrm{Cu} / \mathrm{Zn}-\mathrm{SOD}$ isoform. The isoforms were detected in the control and other treated plants, but the intensity of bands was higher in $4 \mathrm{~g}$ acceleration, especially at $100 \mathrm{~Hz}$ compared to control.

The activity of POX significantly increased under different frequencies of vibration, and $100 \mathrm{~Hz}$ frequency showed the optimum POX activity (Figure 5(a)). A $34.84 \%$ and $16.86 \%$ increase of POX activity was observed at $100 \mathrm{~Hz}$ frequency in LS and RS compared to control, respectively. 


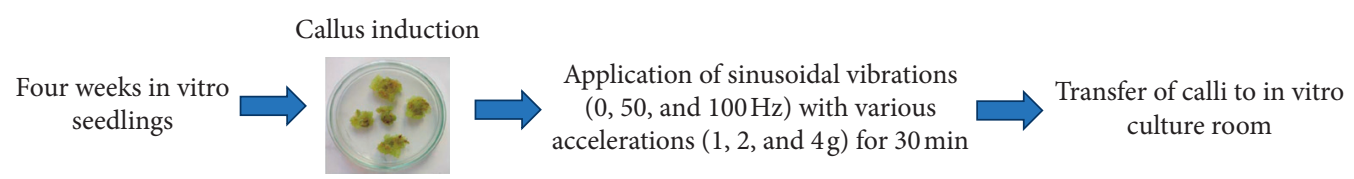

FIgURE 1: Depiction of application of vibration and acceleration treatments on A. gilanica calli.

TABle 1: Effect of different sinusoidal vibrations $(0,50$, and $100 \mathrm{~Hz})$ and accelerations $(1,2$, and $4 \mathrm{~g})$ on growth parameters, relative water content (RWC), protein, and total carbohydrate of two Anthemis gilanica callus sources.

\begin{tabular}{|c|c|c|c|c|c|c|}
\hline Callus source & Vibration $(\mathrm{Hz})$ & Acceleration (g) & Fresh weight (g/plant) & Dry weight (g/plant) & RWC (\%) & Protein $(\mathrm{mg} / \mathrm{g} \mathrm{FW})$ \\
\hline \multirow{9}{*}{ LS } & 0 & 1 & $4.91 \pm 0.131^{\mathrm{cd}}$ & $0.39 \pm 0.031^{\mathrm{d}}$ & $49.6 \pm 1.53^{\mathrm{b}}$ & $29.1 \pm 2.67^{\mathrm{cd}}$ \\
\hline & & 2 & - & - & - & - \\
\hline & & 4 & - & - & - & - \\
\hline & 50 & 1 & $6.92 \pm 0.25^{\mathrm{a}}$ & $0.57 \pm 0.023^{\mathrm{a}}$ & $59.3 \pm 1.44^{\mathrm{a}}$ & $46.3 \pm 2.55^{\mathrm{a}}$ \\
\hline & & 2 & $5.22 \pm 0.33^{\mathrm{c}}$ & $0.52 \pm 0.043^{\mathrm{ab}}$ & $51.5 \pm 1.40^{\mathrm{b}}$ & $40.1 \pm 1.04^{\mathrm{b}}$ \\
\hline & & 4 & $4.24 \pm 0.22^{\mathrm{d}}$ & $0.39 \pm 0.029^{\mathrm{d}}$ & $30.8 \pm 1.52^{\mathrm{d}}$ & $32.3 \pm 1.39^{\mathrm{c}}$ \\
\hline & 100 & 1 & $5.90 \pm 0.34^{\mathrm{bc}}$ & $0.51 \pm 0.025^{\mathrm{b}}$ & $57.3 \pm 1.24^{\mathrm{a}}$ & $39.4 \pm 1.29^{\mathrm{b}}$ \\
\hline & & 2 & $5.43 \pm 0.32^{\mathrm{c}}$ & $0.46 \pm 0.032^{\mathrm{bc}}$ & $50.3 \pm 1.32^{\mathrm{b}}$ & $32.7 \pm 1.06^{\mathrm{c}}$ \\
\hline & & 4 & $4.13 \pm 0.29 \mathrm{~d}$ & $0.44 \pm 0.029^{c}$ & $38.7 \pm 3.29^{c}$ & $24.2 \pm 1.52^{\mathrm{d}}$ \\
\hline \multirow{9}{*}{ RS } & 0 & 1 & $3.22 \pm 0.12^{c}$ & $0.29 \pm 0.014^{\mathrm{d}}$ & $51.4 \pm 2.08^{\mathrm{bc}}$ & $23.7 \pm 1.61^{\mathrm{bc}}$ \\
\hline & & 2 & - & - & - & - \\
\hline & & 4 & - & - & - & - \\
\hline & 50 & 1 & $4.52 \pm 0.14^{\mathrm{a}}$ & $0.44 \pm 0.014^{\mathrm{a}}$ & $65.4 \pm 1.14^{\mathrm{a}}$ & $40.2 \pm 2.28^{\mathrm{a}}$ \\
\hline & & 2 & $4.22 \pm 0.19^{\mathrm{a}}$ & $0.38 \pm 0.029^{b}$ & $58.2 \pm 1.18^{\mathrm{b}}$ & $25.9 \pm 1.77^{\mathrm{b}}$ \\
\hline & & 4 & $4.03 \pm 0.15^{\mathrm{b}}$ & $0.31 \pm 0.030^{c}$ & $44.2 \pm 1.15^{\mathrm{cd}}$ & $20.5 \pm 1.62^{\mathrm{c}}$ \\
\hline & 100 & 1 & $3.91 \pm 0.24^{\mathrm{b}}$ & $0.35 \pm 0.021^{b c}$ & $61.3 \pm 1.21^{\mathrm{ab}}$ & $27.4 \pm 1.21^{\mathrm{b}}$ \\
\hline & & 2 & $2.83 \pm 0.83^{c}$ & $0.28 \pm 0.022^{\mathrm{cd}}$ & $55.8 \pm 1.19^{\mathrm{b}}$ & $22.1 \pm 1.04^{\mathrm{bc}}$ \\
\hline & & 4 & $3.01 \pm 0.17^{\mathrm{c}}$ & $0.31 \pm 0.012^{c}$ & $40.5 \pm 1.17^{\mathrm{d}}$ & $19.4 \pm 1.52^{\mathrm{c}}$ \\
\hline
\end{tabular}

Values are given as mean \pm SE $(n=5)$ in each group. Different letters indicate significant differences at $P<0.05$ (LSD). LS, leaf segments; RS, root segments.

POX activity was higher in RS calli than that of LS calli. The mixed effect of acceleration and vibration significantly decreased POX activity at $2 \mathrm{~g}$ and $4 \mathrm{~g}$ acceleration. At $100 \mathrm{~Hz}$ frequency, POX activity induced a $34.82 \%$ and $22.88 \%$ decrease of POX activity at $2 \mathrm{~g}$ and $4 \mathrm{~g}$ acceleration in RS calli as compared with vibration alone, respectively. The electrophoretic profiles of POX revealed four isoforms in LS calli and two isoforms in RS calli. POXs from 1 to 4 were observed in LS calli (Figure 5(b)). The POX1, POX2, and POX3 were identified in control and vibrated plants with or without acceleration, but the intensity of the mentioned bands was lower at $4 \mathrm{~g}$ acceleration as compared to the control. POX4 was observed just in control and disappeared under vibration and acceleration. In RS calli, POX1 and POX2 were observed in all vibration treatments and control; however, the intensity of bands was higher at $50 \mathrm{~Hz}$ and $100 \mathrm{~Hz}$ frequencies. Application of acceleration decreased the intensity of bands, especially at $4 \mathrm{~g}$ acceleration.

The activity of APX significantly increased in both LS and RS calli of A. gilanica $(P<0.05)$ (Figure 6(a)), and the maximum activity was determined at $50 \mathrm{~Hz}$ frequency of vibration compared to the control. The mixed effect of acceleration and vibration increased more APX activity than that of vibration alone. Frequency of $50 \mathrm{~Hz}$ with $4 \mathrm{~g}$ acceleration caused $46.34 \%$ and $58.33 \%$ increase of APX activity in LS and RS calli comparing to vibration alone, respectively.

PPO activity significantly decreased under vibration and $1 \mathrm{~g}$ acceleration, and minimum activity was found out at
$50 \mathrm{~Hz}$ frequency $(P<0.05)$ (Figure 6(b)). A $54.16 \%$ and $57.14 \%$ decrease of PPO activity was identified at $50 \mathrm{~Hz}$ frequency in both LS and RS calli compared to the control, respectively. The mixed effect of acceleration and vibration increased the PPO activity compared to vibration alone, especially in RS calli, and an $84.61 \%$ and $129.23 \%$ increase of PPO activity was observed at $50 \mathrm{~Hz}$ frequency with $2 \mathrm{~g}$ and $4 \mathrm{~g}$ acceleration as compared to vibration alone, respectively (Figure 6(b)).

\section{Discussion}

This study was performed to establish the effect of acceleration on vibration tolerance mechanisms in A. gilanica callus. Growth alteration is the most distinct plant reaction to stress, and the growth level changes between plant species, genotypes, and organs. In this research, vibration significantly increased fresh and dry weight, RWC, and protein content, and high acceleration decreased these parameters in response to vibration. Kang et al. [12] showed that the growth and protein content of Camptotheca acuminata calli improved under vibration. Hassanpour et al. [36] also reported the positive relation of growth and RWC content under vibration, which may be related to osmolytes accumulation [37]. Salami et al. [38] displayed that growth induction in Matricaria chamomilla L. callus can be associated with an increment in protein, proline, total phenol content, and antioxidative enzyme activities. Mechanical vibration 


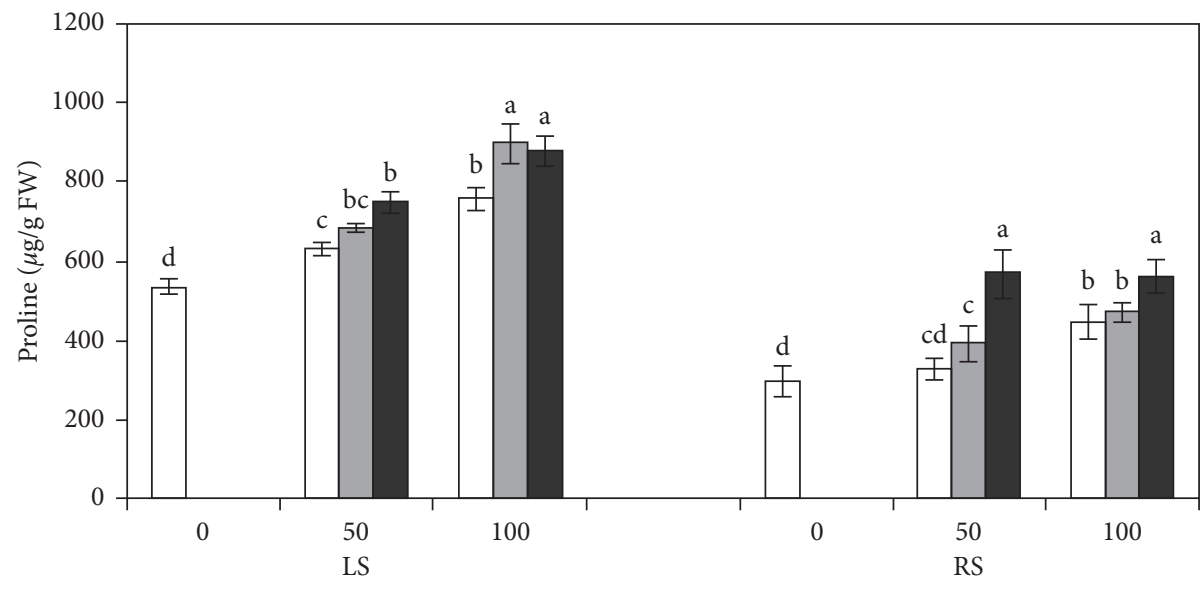

Vibration $(\mathrm{Hz})$

$$
\begin{array}{r}
\square 1 \mathrm{~g} \\
\square 2 \mathrm{~g} \\
\square 4 \mathrm{~g}
\end{array}
$$

(a)

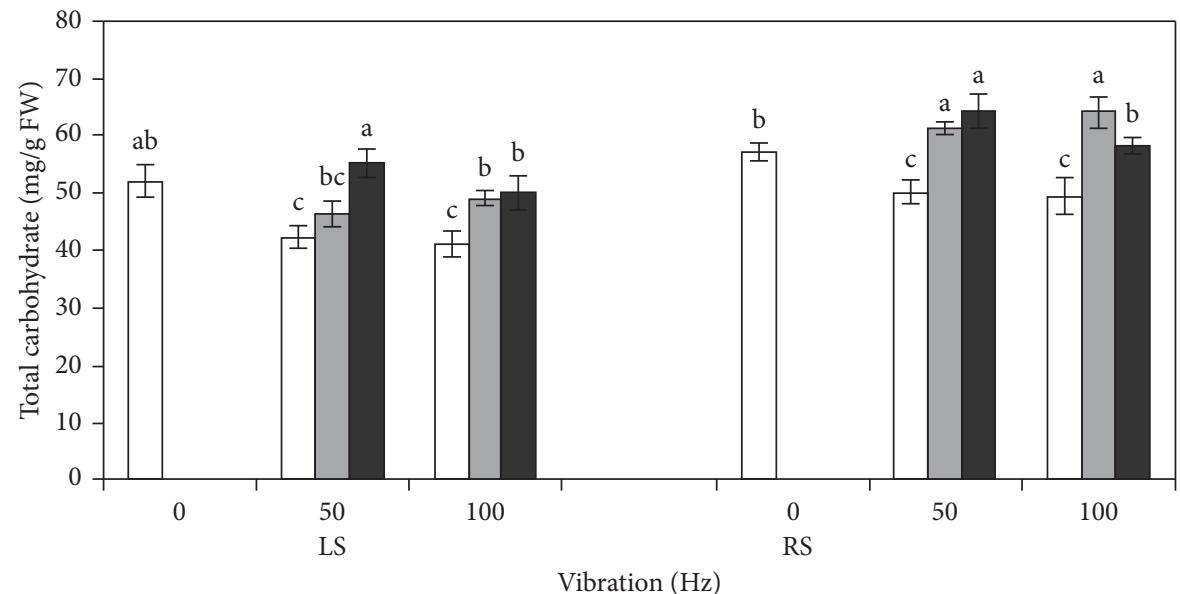

$$
\begin{aligned}
& \square 1 \mathrm{~g} \\
& \square 2 \mathrm{~g} \\
& \square 4 \mathrm{~g}
\end{aligned}
$$

Vibration $(\mathrm{Hz})$

(b)

FIGURE 2: Effect of different sinusoidal vibrations $(0,50$, and $100 \mathrm{~Hz})$ and accelerations $(1,2$, and $4 \mathrm{~g})$ on proline (a) and total carbohydrate (b) accumulation of A. gilanica calli. Bars indicate mean $\pm \mathrm{SE}(n=4)$ in each group. Different letters indicate significant differences at $P<0.05$ (LSD).

induces some signals such as cytoplasmic $\mathrm{Ca}^{2+}$ and protein kinases $[39,40]$, which can have impact on gene expression associated with antioxidant system induction, lipid peroxidation decline, osmoregulation, cell division, and growth [2]. Unlike animal cells, there are no data about acceleration effects on plant cells. In osteoblast cells, high-frequency vibration $(20 \mathrm{~Hz})$ with low acceleration $(0.05 \mathrm{~g})$ increased cell proliferation and at $60 \mathrm{~Hz}$ and $0.13 \mathrm{~g}$ induced metabolic activity [13]. Also, bone formation is promoted by low acceleration [10]. High accelerations usually cause a higher force and can shift the resonance frequency of vibration [41]. It seems that an increase of the acceleration level from $1 \mathrm{~g}$ to $4 \mathrm{~g}$ increases the mechanical resonance of the vibration on cells and decreases protein content and cell growth. On the other hand, decreased growth by mechanical stress may be due to the disruption of hormone hemostasis in the cells $[42,43]$.

Proline is a common compound in response to different abiotic stresses [37, 44]. Besides their role in osmoregulation, proline has a key role in stabilizing subcellular structures and scavenging of free radicals under stress. Indeed, proline accumulation can indicate the level of plant tolerance to stress conditions $[45,46]$. Also, proline and ROS can facilitate the activation of $\mathrm{Ca}^{2+}$ channels along with $\mathrm{K}^{+}$ channels under mechanical stress [17]. In this research, vibration increased significantly proline accumulation, and with an increase of the acceleration level, this parameter induced especially in LS calli (Figure 2(a)). These results 


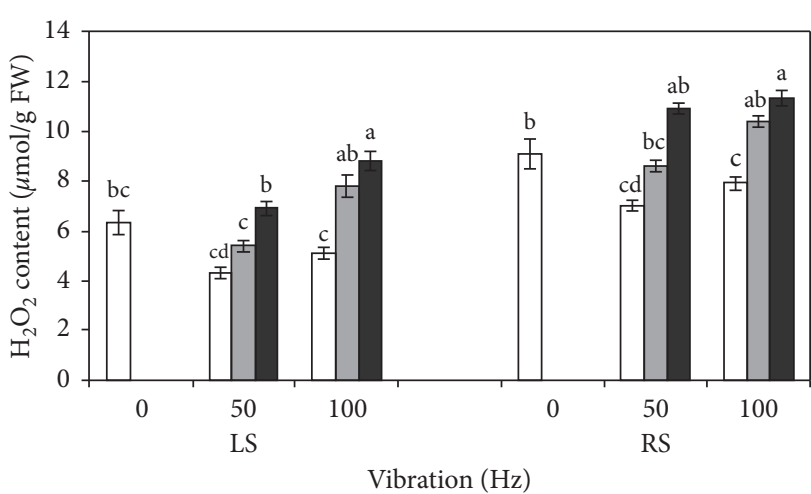

$\square 1 \mathrm{~g}$

$\square 2 \mathrm{~g}$

口 $4 \mathrm{~g}$

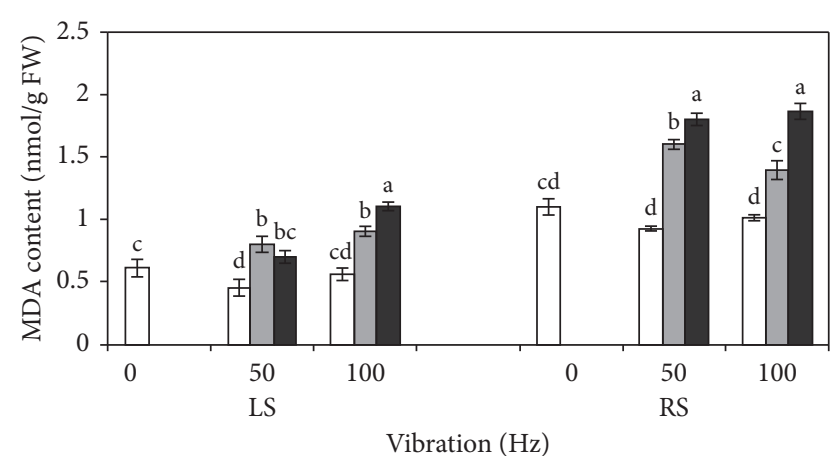

$\square 1 \mathrm{~g}$

$\square 2 \mathrm{~g}$

口 $4 \mathrm{~g}$

(a)

(b)

FIGURE 3: Effect of different sinusoidal vibrations $(0,50$, and $100 \mathrm{~Hz})$ and accelerations $(1,2$, and $4 \mathrm{~g})$ on $\mathrm{H}_{2} \mathrm{O}_{2}$ (a) and MDA contents (b) of A. gilanica calli. Bars indicate mean $\pm \mathrm{SE}(n=4)$ in each group. Different letters indicate significant differences at $P<0.05$ (LSD).

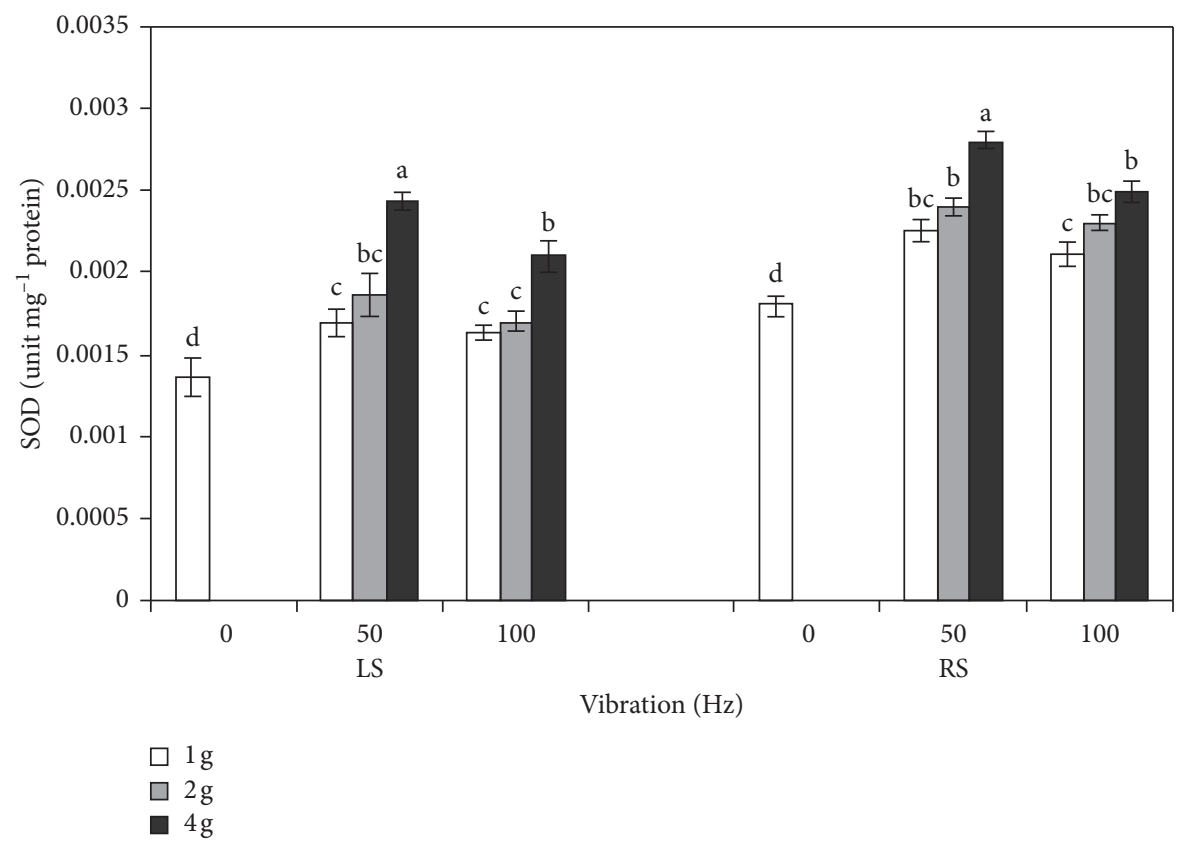

(a)

Figure 4: Continued. 


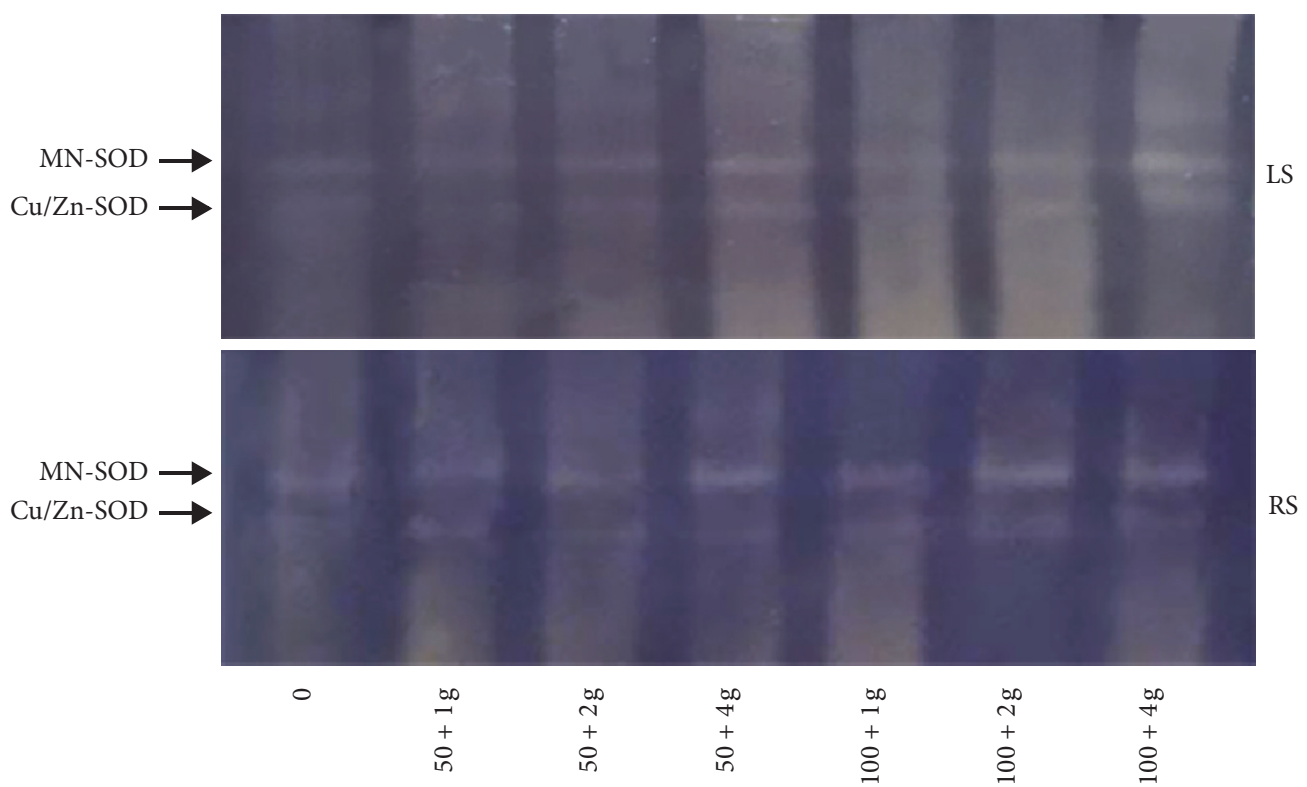

(b)

Figure 4: Effect of different sinusoidal vibrations $(0,50$, and $100 \mathrm{~Hz})$ and accelerations $(1,2$, and $4 \mathrm{~g})$ on the activities (a) and isoform patterns (b) of SOD enzyme in A. gilanica calli. Bars indicate mean \pm SE $(n=4)$ in each group. Different letters indicate significant differences at $P<0.05$ (LSD).

suggested that acceleration can act as an osmotic adjustment cause and affects intracellular osmotic pressure. Increased pyrroline-5-carboxylate synthase activity and following proline content have been reported earlier in tobacco suspension cells [37]. It seems that vibration under higher acceleration can induce more oxidative stress than vibration alone, and osmolyte accumulation may relate to stress tolerance in A. gilanica calli.

Carbohydrates serve as an energy source under stress and provide carbon skeletons for both catabolic and anabolic reactions. Also, carbohydrates preserve membrane and protein structures and prevent oxidative stress injury [47]. Rolland et al. [48] showed that soluble sugars could activate crosstalk between hormonal signaling and gene expression in plants. In this study, vibration reduced total carbohydrate content at $50 \mathrm{~Hz}$ and $100 \mathrm{~Hz}$ frequencies, and with an increase of the acceleration level, the carbohydrate accumulation increased in comparison with control (Figure 2(b)). Increased carbohydrate content has been reported early in Dendranthema morifolium [49] and chrysanthemum [50] under mechanical stress. It seems that an increase of carbohydrates under acceleration may act as a factor in cell protection against oxidative damage. Furthermore, this might have resulted from the increased calli area, which induced light absorption and photosynthetic rate, consequently leading to induction in the overall metabolite contents. On the other hand, enhancement of carbohydrate content aids the $A$. gilanica calli to maintain their water balance and growth in a better way.

Different abiotic stresses lead to the production of more ROS constitutes including $\mathrm{O}_{2}{ }^{-}, \mathrm{H}_{2} \mathrm{O}_{2}$, and $\mathrm{OH}^{-}$in plants $[51,52]$, and the cellular damages are revealed in the form of degradation of biomolecules such as proteins, lipids, and
DNA, which ultimately amalgamate in oxidative stress and cellular death. MDA is the most frequent biomarker of lipid peroxidation that determines oxidative stress in cells $[53,54]$. In this research, $\mathrm{H}_{2} \mathrm{O}_{2}$ and MDA levels significantly decreased under vibration, especially at $100 \mathrm{~Hz}$ in both LS and RS calli, and with an increase of the acceleration level, the mentioned parameters increased as compared to vibration alone (Figure 3). The decreased MDA level has been previously notified in Triticum aestivum [14] and Nicotiana tabacum under vibration [37]. The reduction of MDA content may illuminate that vibration can diminish oxidative damage and maintain membrane stability. There are no data about the effect of high acceleration on plant cell membrane damage. It seems that the reduction of membrane stability in A. gilanica calli can be related to higher production of ROS constitutes and following oxidative damage under the high acceleration level.

Higher antioxidant activity is positively associated with an increase in stress tolerance in cells $[12,14]$. ROS signals activate several different defense pathways such as antioxidant enzymes in cell organelles. Peroxisomes contain ROS regulatory enzymatic systems including CAT, ascorbateglutathione cycle, and SOD in both peroxisomal matrix and membrane [55]. SOD is a key antioxidant enzyme to catalyzing of the toxic superoxide radical level to molecular oxygen and $\mathrm{H}_{2} \mathrm{O}_{2}$, and other antioxidative enzymes such as CAT, POX, and APX complement the process of ROS elimination by transforming $\mathrm{H}_{2} \mathrm{O}_{2}$ into water and molecular oxygen $[55,56]$. In this study, SOD activity increased under vibration, and SOD activity continuously induced with an increase of the acceleration level, especially at $4 \mathrm{~g}$ (Figure 4(a)). Band intensity of $\mathrm{Mn}-\mathrm{SOD}$ and $\mathrm{Cu} / \mathrm{Zn}-\mathrm{SOD}$ also increased at $4 \mathrm{~g}$ acceleration (Figure $4(\mathrm{~b})$ ). The increased 


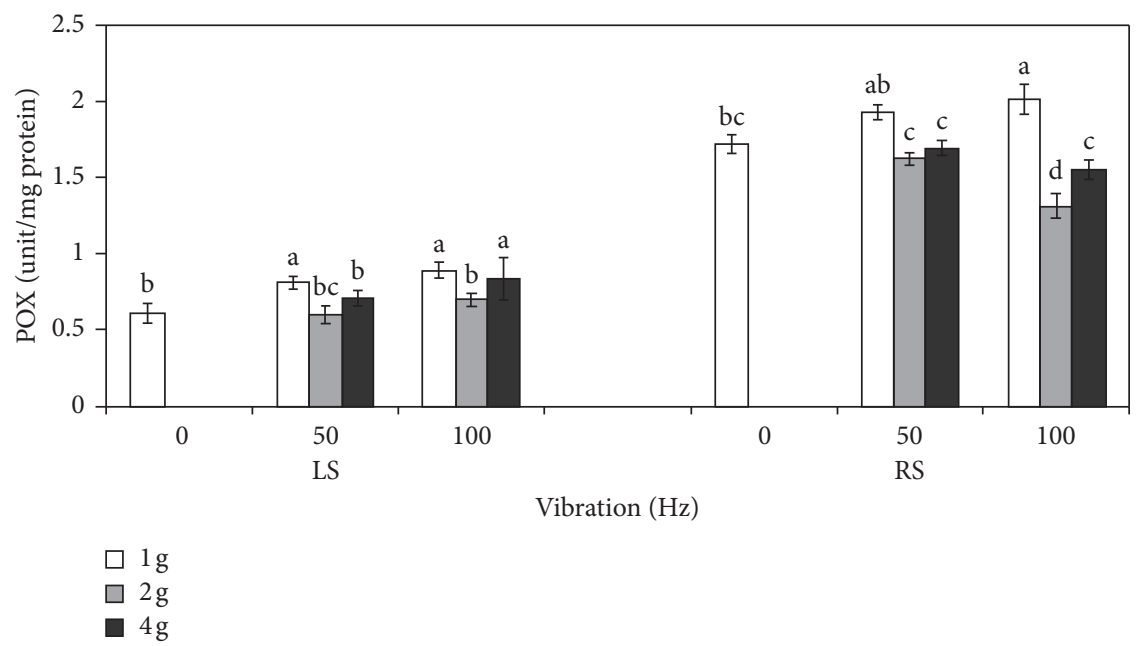

(a)

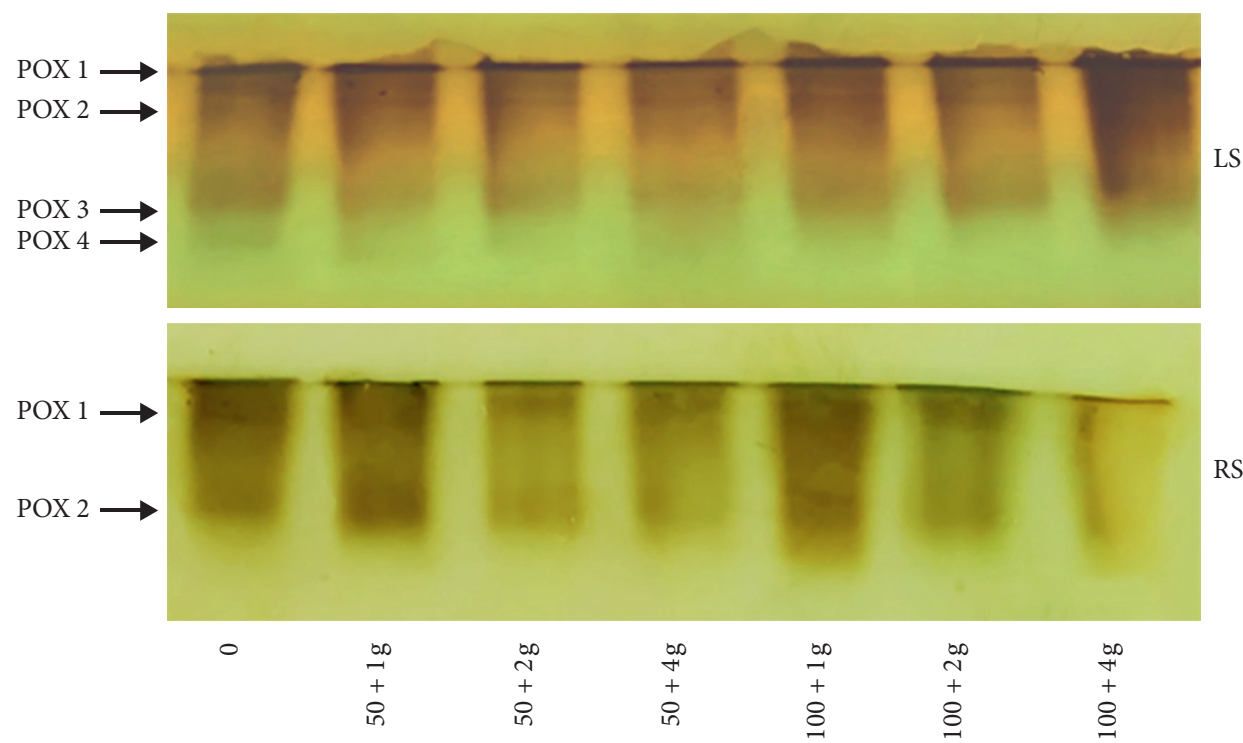

(b)

Figure 5: Effect of different sinusoidal vibrations $(0,50$, and $100 \mathrm{~Hz})$ and accelerations $(1,2$, and $4 \mathrm{~g})$ on the activities (a) and isoform patterns (b) of POX enzyme in A. gilanica calli. Bars indicate mean \pm SE $(n=4)$ in each group. Different letters indicate significant differences at $P<0.05$ (LSD).

SOD activity might be considered as an efficient system to protect cell organelles such as chloroplasts from ROS and has been reported in Actinidia chinensis Planch. [57], Triticum aestivum [14], and Mentha pulegium [58]. Hassanpour et al. [36] displayed different SOD isoforms, including $\mathrm{Cu}$ / $\mathrm{Zn}-\mathrm{SOD}, \mathrm{Mn}-\mathrm{SOD}$, and Fe-SOD, which are responsible for $\mathrm{O}_{2}{ }^{-}$scavenging under vibration. It seems that an increase of acceleration levels together with vibration imposed more stress than vibration alone in A. gilanica calli, and cells need more SOD activity for $\mathrm{O}_{2}{ }^{-}$radical scavenging.

POX, APX, and CAT are the main enzymes responsible for $\mathrm{H}_{2} \mathrm{O}_{2}$ scavenging under abiotic stress $[59,60]$. Enhanced activity of antioxidant enzymes could protect plant cells against oxidative injury $[61,62]$. Our results showed that vibration improved POX and APX activities in both LS and RS calli as compared to the control (Figures 5(a) and 6(a)), indicating that the antioxidant defense system could keep $\mathrm{H}_{2} \mathrm{O}_{2}$ at a low level and improve calli growth. An increase of the acceleration level caused an increment of APX activity and a decrease of POX activity under vibration (Figures 5(a) and $6(\mathrm{a})$ ). The intensity of POX1, 2, and 3 bands markedly decreased with the increase in the acceleration level, especially at $4 \mathrm{~g}$, and POX4 also disappeared under vibration (Figure 5(b)). Decreased POX activity and band intensity may show that this enzyme has the low duty or is inactivated under high acceleration and can be considered as one of the causes of growth reduction.

Polyphenol oxidases (PPOs) catalyze the oxidation of some phenols to chinones and produce brown or black pigments in plant tissues. In our research, PPO activity decreased markedly under vibration alone but induced with an increase of the acceleration level in both LS and RS calli 


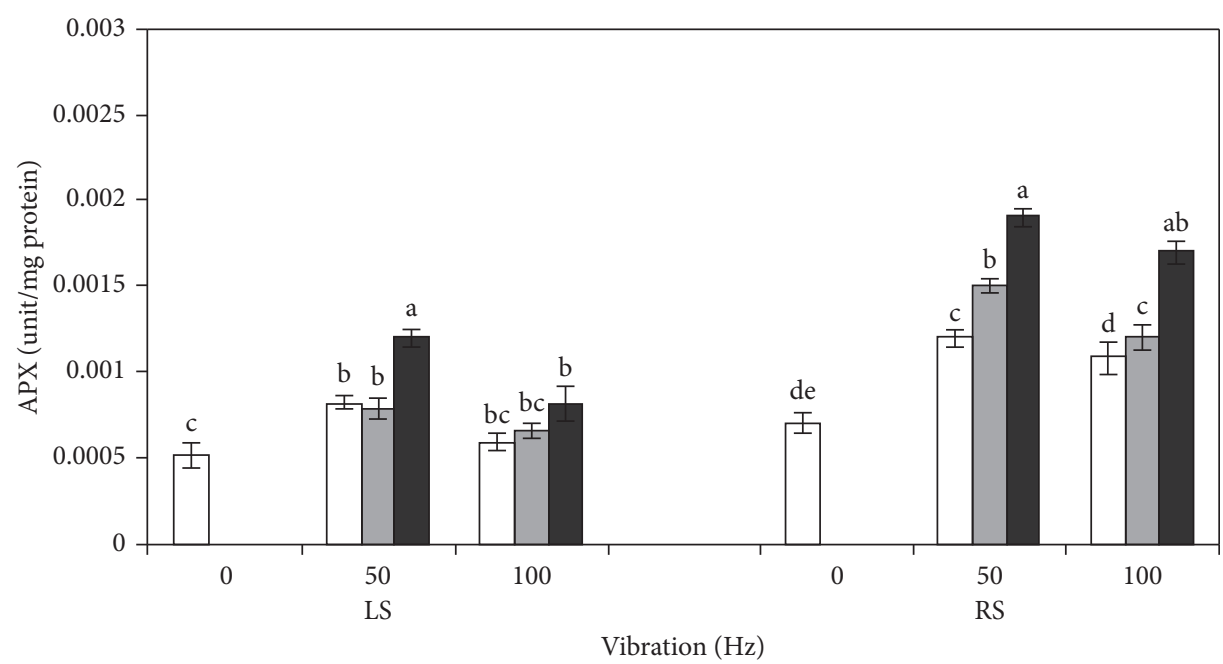

$$
\begin{array}{r}
\square 1 \mathrm{~g} \\
\square 2 \mathrm{~g} \\
\square 4 \mathrm{~g}
\end{array}
$$

(a)

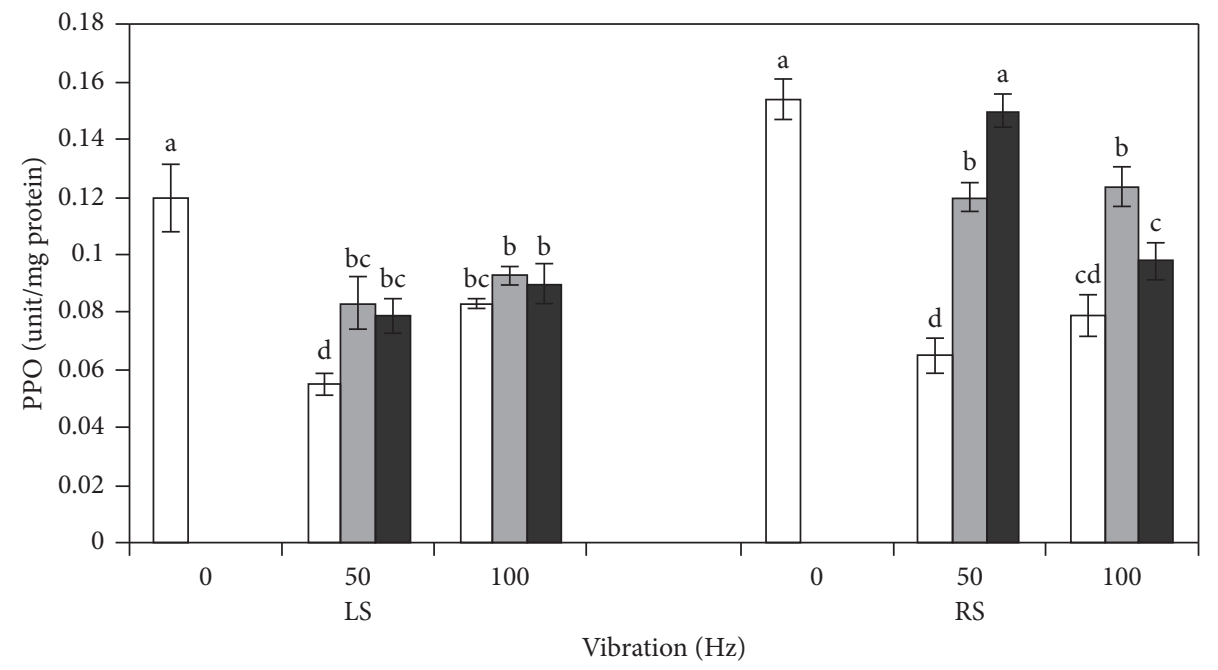

$$
\begin{array}{r}
\square 1 \mathrm{~g} \\
\square 2 \mathrm{~g} \\
\square 4 \mathrm{~g}
\end{array}
$$

(b)

Figure 6: Effect of different sinusoidal vibrations (0, 50, and $100 \mathrm{~Hz})$ and accelerations (1, 2, and $4 \mathrm{~g})$ on APX (a) and PPO (b) activities in A. gilanica calli. Bars indicate mean \pm SE $(n=4)$ in each group. Different letters indicate significant differences at $P<0.05$ (LSD).

(Figure 6(b)). In contrast to our results, Wu and Lin [63] showed that ultrasound vibration markedly induced PPO activity and polyphenol production in Panax ginseng cells and can be related to enzymatic browning and membrane permeabilization. It seems that acceleration maximized oxidative stress damage, reduced growth, and induced calli browning in A. gilanica calli by induction of PPO activity.

\section{Conclusions}

Understanding of the mechanisms by which plant cells change their defense mechanisms for stress tolerance is still limited. However, the identification of the effective frequency of vibration and acceleration as a new triggering antioxidant mechanism and growth will help advance our knowledge in this field. The increase of the acceleration level decreased growth and protein content and induced browning of the callus tissue, especially at $4 \mathrm{~g}$ acceleration in RS calli. Proline and carbohydrate contents, lipid peroxidation, and some oxidative enzyme activities were also induced under high acceleration. Although the effective frequency of vibration can induce some defense responses such as antioxidative enzymes and osmolyte accumulation in callus cells, the presence of high acceleration intensified 
the vibration resonance effect on cell organelles by reduction of RWC and concomitant disruption of cell adaptive mechanisms through induction of membrane and oxidative damage. However, there is effective acceleration for induction of growth and defense mechanisms, which needs to be investigated in the future.

\section{Data Availability}

The data used to support the findings of this study are available from the corresponding author upon request.

\section{Conflicts of Interest}

The authors declare that they have no conflicts of interest.

\section{Authors' Contributions}

SS participated in the bench experiments and contributed to analyze data. V. N. and $\mathrm{H}$. H. have designed and provided overall supervision of the study and organized the article. All authors read and approved the final draft of the article.

\section{Acknowledgments}

The authors thank the Aerospace Research Institute of Iran for their research supports.

\section{References}

[1] C. A. Mitchell, "Recent advances in plant response to mechanical stress: theory and application," HortScience, vol. 31, no. 1, pp. 31-35, 1996.

[2] N. Wang, J. Butler, and D. Ingber, "Mechanotransduction across the cell surface and through the cytoskeleton," Science, vol. 260, no. 5111, pp. 1124-1127, 1993.

[3] J. Braam, "In touch: plant responses to mechanical stimuli," The New Phytologist, vol. 165, no. 2, pp. 373-389, 2005.

[4] S. Ochatt, C. Pech, R. Grewal, C. Conreux, M. Lulsdorf, and L. Jacas, "Abiotic stress enhances androgenesis from isolated microspores of some legume species (Fabaceae)," Journal of Plant Physiology, vol. 166, no. 12, pp. 1314-1328, 2009.

[5] T. M. Lynch and P. M. Lintilhac, "Mechanical signals in plant development: a new method for single cell studies," Developmental Biology, vol. 181, no. 2, pp. 246-256, 1997.

[6] K. Niklas, "Effects of vibration on mechanical properties and biomass allocation pattern of Capsella bursa-pastoris (Cruciferae)," Annals of Botany, vol. 82, no. 2, pp. 147-156, 1998.

[7] A. Uchida and K. T. Yamamoto, "Effects of mechanical vibration on seed germination of Arabidopsis thaliana (L.) Heynh," Plant and Cell Physiology, vol. 43, no. 6, pp. 647-651, 2002.

[8] C. H. Yu, S. B. Seob, S. R. Kangb, K. Kimc, and T. K. Kwon, "Effect of vibration on muscle strength imbalance in lower extremity using multicontrol whole body vibration platform," Bio-Medical Materials and Engineering, vol. 26, no. 1, pp. S673-S683, 2015.

[9] L. Meirovitch, Fundamentals of Vibrations, McGraw-Hill, New York, NY, USA, International edition, 2001.

[10] R. Garman, G. Gaudette, L.-R. Donahue, C. Rubin, and S. Judex, "Low-level accelerations applied in the absence of weight bearing can enhance trabecular bone formation,"
Journal of Orthopaedic Research, vol. 25, no. 6, pp. 732-740, 2007.

[11] W. Bochu, L. Xuefeng, L. Yiyao, D. Chuanren, and A. Sakanishi, "The effects of mechanical vibration on the microstructure of Gerbera jamesonii acrocarpous callus," Colloids and Surfaces B: Biointerfaces, vol. 23, no. 1, pp. 1-5, 2002.

[12] D. Kang, H. Zhang, Q. Zeng, X. Mo, Y. Wang, and D. Yang, "Response of Camptotheca acuminata calli stimulated by mechanical vibration," Acta Physiologiae Plantarum, vol. 33, no. 3, pp. 711-716, 2011.

[13] N. Rosenberg, M. Levy, and M. Francis, "Experimental model for stimulation of cultured human osteoblast-like cells by high frequency vibration," Cytotechnology, vol. 39, no. 3, pp. 125-130, 2002.

[14] Y.-P. Chen, Q. Liu, X.-Z. Yue, Z.-W. Meng, and J. Liang, "Ultrasonic vibration seeds showed improved resistance to cadmium and lead in wheat seedling," Environmental Science and Pollution Research, vol. 20, no. 7, pp. 4807-4816, 2013.

[15] L. Benikhlef, F. L'Haridon, E. Abou-Mansour et al., "Perception of soft mechanical stress in Arabidopsis leaves activates disease resistance," BMC Plant Biology, vol. 13, no. 1, p. 133, 2013.

[16] R. H. Hassanien, T.-Z. Hou, Y.-F. Li, and B.-M. Li, “Advances in effects of sound waves on plants," Journal of Integrative Agriculture, vol. 13, no. 2, pp. 335-348, 2014.

[17] R. C. Mishra, R. Ghosh, and H. Bae, "Plant acoustics: in the search of a sound mechanism for sound signaling in plants," Journal of Experimental Botany, vol. 67, no. 15, pp. 4483-4494, 2016.

[18] V. Mozaffarian, A Dictionary of Iranian Plant Names, Farhang Moaser, Tehran, Iran, 1996.

[19] F. Collu, L. Bonsignore, M. Casu, C. Floris, J. Gertsch, and F. Cottiglia, "New cytotoxic saturated and unsaturated cyclohexanones from Anthemis maritima," Bioorganic \& Medicinal Chemistry Letters, vol. 18, no. 5, pp. 1559-1562, 2008.

[20] V. Saroglou, A. Karioti, A. Rancic et al., "Sesquiterpene lactones fromAnthemis melanolepisand their antibacterial and cytotoxic activities. Prediction of their pharmacokinetic profile," Journal of Natural Products, vol. 73, no. 2, pp. 242-246, 2010.

[21] N. Bai, K. He, M. Roller et al., "Flavonoid glycosides from Microtea debilis and their cytotoxic and anti-inflammatory effects," Fitoterapia, vol. 82, no. 2, pp. 168-172, 2011.

[22] G. Uzer, S. L. Manske, M. E. Chan et al., "Separating fluid shear stress from acceleration during vibrations in vitro: identification of mechanical signals modulating the cellular response," Cellular and Molecular Bioengineering, vol. 5, no. 3, pp. 266-276, 2012.

[23] T. Murashige and F. Skoog, "A revised medium for rapid growth and bio assays with tobacco tissue cultures," Physiologia Plantarum, vol. 15, no. 3, pp. 473-497, 1962.

[24] M. Pieczynski, W. Marczewski, J. Hennig et al., "Downregulation of CBP80gene expression as a strategy to engineer a drought-tolerant potato," Plant Biotechnology Journal, vol. 11, no. 4, pp. 459-469, 2013.

[25] R. L. Heath and L. Packer, "Photoperoxidation in isolated chloroplasts," Archives of Biochemistry and Biophysics, vol. 125, no. 1, pp. 189-198, 1968.

[26] V. Velikova, I. Yordanov, and A. Edreva, "Oxidative stress and some antioxidant systems in acid rain-treated bean plants," Plant Science, vol. 151, no. 1, pp. 59-66, 2000. 
[27] L. S. Bates, R. P. Waldren, and I. D. Teare, "Rapid determination of free proline for water-stress studies," Plant and Soil, vol. 39, no. 1, pp. 205-207, 1973.

[28] M. Dubois, K. A. Gilles, J. K. Hamilton, P. A. Rebers, and F. Smith, "Colorimetric method for determination of sugars and related substances," Analytical Chemistry, vol. 28, no. 3, pp. 350-356, 1956.

[29] M. M. Bradford, "A rapid and sensitive method for the quantitation of microgram quantities of protein utilizing the principle of protein-dye binding," Analytical Biochemistry, vol. 72, no. 1-2, pp. 248-254, 1976.

[30] C. O. Beauchamp and I. Fridovich, "Isozymes of superoxide dismutase from wheat germ," Biochimica et Biophysica Acta (BBA)-Protein Structure, vol. 317, no. 1, pp. 50-64, 1973.

[31] Z. Miszalski, I. Slesak, E. Niewiadomska, R. Baczek-Kwinta, U. Luttge, and R. Ratajczak, "Subcellular localization and stress responses of superoxide dismutase isoforms from leaves in the C3-CAM intermediate halophyte Mesembryanthemum crystallinum L," Plant, Cell and Environment, vol. 21, no. 2, pp. 169-179, 1998.

[32] B. Chance and A. C. Maehly, "Assay of catalases and peroxidases," Methods in Enzymology, vol. 2, pp. 764-775, 1955.

[33] L. C. Van Loon and J. L. M. C. Geelen, "The relation of polyphenol oxidase and peroxidase to symptom expression in tobacco var. "Samsun NN" after infection with tobacco mosaic virus," Acta Phytopathol Acad Sci Hung, vol. 6, pp. 9-20, 1971.

[34] J. Raymond, N. Rakariyatham, and J. L. Azanza, "Purification and some properties of polyphenoloxidase from sunflower seeds," Phytochemistry, vol. 34, no. 4, pp. 927-931, 1993.

[35] Y. Nakano and K. Asada, "Hydrogen peroxide is scavenged by ascorbate specific peroxidase in spinach chloroplasts," Plant and Cell Physiology, vol. 22, pp. 867-880, 1981.

[36] H. Hassanpour, V. Niknam, and B. S. Haddadi, "High-frequency vibration improve callus growth via antioxidant enzymes induction in Hyoscyamus kurdicus," Plant Cell, Tissue and Organ Culture (PCTOC), vol. 128, no. 1, pp. 231-241, 2017.

[37] Z. G. Li and M. Gong, "Mechanical stimulation-induced chilling tolerance in tobacco suspension cultured cells and its relation to proline," Russian Journal of Plant Physiology, vol. 60, no. 1, pp. 149-154, 2013.

[38] S. Salami, H. Hassanpour, and V. Niknam, "Induction of growth and antioxidant defense mechanisms in Matricaria chamomilla L. callus by Vibration," In Vitro Cellular \& Developmental Biology-Plant, vol. 56, no. 5, p. 644, 2020.

[39] L. Bogre, W. Ligterink, I. Meskiene et al., "Wounding induces the rapid and transient activation of a specific MAP kinase pathway," The Plant Cell, vol. 9, pp. 75-83, 1997.

[40] M. Piotrowski, H. Liss, and E. W. Weiler, "Touch-induced protein phosphorylation in mechanosensitive tendrils of Bryonia dioica Jacq," Journal of Plant Physiology, vol. 147, no. 5, pp. 539-546, 1996.

[41] R. L. Filler, "The acceleration sensitivity of quartz crystal oscillators: a review," IEEE Transactions on Ultrasonics, Ferroelectrics and Frequency Control, vol. 35, no. 3, pp. 297-305, 1988.

[42] N. L. Biddington, "The effects of mechanically-induced stress in plants ? a review," Plant Growth Regulation, vol. 4, no. 2, pp. 103-123, 1986.

[43] I. Potocka and J. Szymanowska-Pulka, "Morphological responses of plant roots to mechanical stress," Annals of Botany, vol. 122, no. 5, pp. 711-723, 2018.

[44] M. S. Osman, A. A. Badawy, A. I. Osman, and A. A. H. A. Latef, "Ameliorative impact of an extract of the halophyte Arthrocnemum macrostachyum on growth and biochemical parameters of soybean under salinity stress," Journal of Plant Growth Regulation, 2020.

[45] L. Szabados and A. Savouré, "Proline: a multifunctional amino acid," Trends in Plant Science, vol. 15, no. 2, pp. 89-97, 2010.

[46] S. Lehmann, D. Funck, L. Szabados, and D. Rentsch, "Proline metabolism and transport in plant development," Amino Acids, vol. 39, no. 4, pp. 949-962, 2010.

[47] M. M. AL-Rumaih and M. M. AL-Rumaih, "Physiological response of two species of datura to uniconazole and salt stress," Journal of Food, Agriculture and Environment, vol. 5, pp. 450-453, 2007.

[48] F. Rolland, E. Baena-Gonzalez, and J. Sheen, "Sugar sensing and signaling in plants: conserved and novel mechanisms," Annual Review of Plant Biology, vol. 57, no. 1, pp. 675-709, 2006.

[49] H. C. Zhao, J. Wu, L. Zheng et al., "Effect of sound stimulation on Dendranthema morifolium callus growth," Colloids and Surfaces B: Biointerfaces, vol. 29, no. 2-3, pp. 143-147, 2003.

[50] J. Yi, W. Bochu, W. Xiujuan et al., "Effect of sound wave on the metabolism of chrysanthemum roots," Colloids and Surfaces B: Biointerfaces, vol. 29, no. 2-3, pp. 115-118, 2003.

[51] S. K. Yadav, "Cold stress tolerance mechanisms in plants. A review," Agronomy for Sustainable Development, vol. 30, no. 3, pp. 515-527, 2010.

[52] A. A. H. A. Latef, M. F. A. Alhmad, M. Kordrostami, A.-B. A.-E. A. Baker, and A. Zakir, "Inoculation with $\mathrm{Azo-}$ spirillum lipoferum or Azotobacter chroococcum reinforces Maize growth by improving physiological activities under saline conditions," Journal of Plant Growth Regulation, vol. 39, pp. 1293-1306, 2020.

[53] T. Demirel and I. Turkan, "Comparative lipid peroxidation, antioxidant defense systems and proline content in roots of two rice cultivars differing in salt tolerance," Environmental and Experimental Botany, vol. 53, pp. 247-257, 2005.

[54] A. A. H. A. Latef, A. Zaid, A.-B. A.-E. Abo-Baker, W. Salem, and M. F. A. Alhmad, "Mitigation of copper stress in Maize by inoculation with Paenibacillus polymyxa and Bacillus circulans," Plants, vol. 9, no. 11, p. 1513, 2020.

[55] J. G. Scandalios, "Oxidative stress: molecular perception and transduction of signals triggering antioxidant gene defenses," Brazilian Journal of Medical and Biological Research, vol. 38, no. 7, pp. 995-1014, 2005.

[56] K. V. Chaitanya, D. Sundar, S. Masilamani, and A. Ramachandra Reddy, "Variation in heat stress-induced antioxidant enzyme activities among three mulberry cultivars," Plant Growth Regulation, vol. 36, no. 2, pp. 175-180, 2002.

[57] Y. Xiaocheng, W. Bochu, D. Chuanren, and D. Chuanyun, "Physiological effect of mechanical vibration on callus of Actinidia chinensis planch," Chinese Journal of Applied and Environmental Biology, vol. 8, no. 1, pp. 36-40, 2002.

[58] E. Ghalkhani, H. Hassanpour, and V. Niknam, "Sinusoidal vibration alleviates salt stress by induction of antioxidative enzymes and anatomical changes in Mentha pulegium (L.)," Acta Physiol Plant, vol. 42, pp. 39-52, 2020.

[59] M. H. Dicko, H. Gruppen, A. S. Traore, A. G. Voragen, and W. J. Van Berkel, "Phenolic compounds and related enzymes as determinants of sorghum for food use," Biotechnology and Molecular Biology Reviews, vol. 1, no. 1, pp. 21-38, 2006.

[60] A. A. H. A Latef, M. Kordrostami, A. Zakir, H. Zaki, and O. M Saleh, "Eustress with $\mathrm{H}_{2} \mathrm{O}_{2}$ facilitates plant growth by improving tolerance to salt stress in two wheat vultivars," Plants, vol. 8, no. 9, p. 303, 2019. 
[61] K. Asada, "The water-water cycle in chloroplasts: scavenging of active oxygens and dissipation of excess photons," Annual Review of Plant Physiology and Plant Molecular Biology, vol. 50, no. 1, pp. 601-639, 1999.

[62] A. A. H. A Latef, M. G. Mostofa, M. M. Rahman, I. B. AbdelFarid, and L. S. P. Tran, "Extracts from yeast and carrot roots enhance Maize performance under seawater-induced salt stress by altering physio-biochemical characteristics of stressed plants," Journal of Plant Growth Regulation, vol. 38, pp. 966-979, 2019.

[63] J. Wu and L. Lin, "Ultrasound-induced stress responses of Panax ginseng cells: enzymatic browning and phenolics production," Biotechnology Progress, vol. 18, no. 4, pp. 862-866, 2002. 